\title{
Basin resources management: simulating soil erosion risk by soil and water assessment tool (SWAT) in Ta Trach river watershed, central Vietnam
}

\author{
Quản lý tài nguyên luu vưc: mô phỏng nguy cơ xói mòn đất bằng công cu đánh \\ giá đất và nước (SWAT) ở lưu vực sông Tả Trạch, miền Trung Việt Nam
}

Research article

Nguyen, Bich Ngoc*; Nguyen, Hoang Khanh Linh

Faculty of Land Resource and Agricultural Environment, Hue University of Agriculture and Forestry, 102 Phung Hung, Hue City, Vietnam

\begin{abstract}
Nowadays, one of the urgent issues in the management of river basin resources as land degradation, especially soil erosion risk occurs due to complex factors of climate, cultivation practices of human and impacting of the operation of socio-economic development taking place in the basin. Soil erosion has been considered as the primary cause of soil degradation since soil erosion leads to the loss of topsoil and soil organic matters, which are essential for the growing of plants. Ta Trach river watershed, is a mountainous basin lying to the West - South of Thua Thien Hue province, having complex terrain. The result of this study showed that the amount of sediment yield accounts for high percentage. The average annual sedimentation is 41.60 tones per hectometer in the period of 2005 to 2010 , soil erosion were classified by 5 levels. In which, the less deleterious erosion level still occupies high percentage with more than $55 \%$ of watershed area. The main area of less deleterious soil erosion was located at high topography and high slope. The area of deleterious soil erosion occupies percentage lower than $22.63 \%$ of the entire basin, but it is also a warning sign to the extent of land degradation taking place in the basin if the erosion rate increases in the future.
\end{abstract}

Ngày nay, một trong nhũng vấn đề cấp bách trong quản lý tài nguyên luu vục sông là sụ thoái hóa đất và đặc biệt là nguy co xói mòn đất xảy ra do yếu tố khí hậu phức tạp, phuơng thức canh tác của con người và tác động của nhũng hoạt động phát triển kinh tế - xã hội đang diến ra ở lư vưcc. Lư vực sông Tả Trạch là một lư vực miền núi nằm về phía Tây - Nam của tỉnh Thù̀a Thiên Huế, có địa hình khá phức tạp. Mục tiêu của nghiên cứu này là ứng dụng công cu SWAT để mô phỏng xói mòn đất ở lưu vực sông Tả Trạch thuộc tỉnh Thù̀a Thiên Huế tù năm 2005 đến năm 2010. Kết quả của nghiên cứu cho thấy lượng đất bồi lắng ở lưu vực chiếm tỷ lệ cao, trung bình mối năm bồi lắng 41.60 tấn/ha trong giai đoạn 2005 đến 2010, mức độ xói mòn được phân cấp thành 5 cấp xói mòn. Trong đó, mức độ xói mòn it nguy hại chiếm ở tỷ lệ cao hơn $55 \%$ diện tích lưu vưc, chủ yếu phân bố ở nhũ̃ng khu vực có địa hình cao, độ dốc lớn. Diện tích xói mòn nguy hại chiếm tỷ lệ thấp hơn 22,63\% diện tích toàn lưu vực nhung đây cũng là một dấu hiệu báo động cho mức độ thoái hóa đất diễn ra ở lư vực trong tương lai nếu mức xói mòn này tăng lên.

Keywords: erosion, GIS, modeling, river basin, SWAT 


\section{Introduction}

Management resource of river basin is one of important factors for sustainable economic development (Geoff Wright et al., 2006). The urgent issue of natural resource management in river basin is the degradation of watershed, including degradation of water resource, soil and environmental pollution occurred in river basin. In recent years, the rapid increase of population and overexploitation of water, land and forest has gradually depleting these resources. Consequently, floods, landslides, sediment flows lead to land getting more and more degraded and severely eroded, affected communities living in the basin. According to statistics, there are 13 million hectares in Vietnam at the risk of erosion, accounting for $40 \%$ of total natural area (Nguyen Anh Hoanh, 2010).

Ta Trach river basin in Thua Thien Hue province has a complex terrain with high mountains, midland and partly plain (People's Committee of Thua Thien Hue province, 2012). Because of climate change and unreasonable strategy of land use, Ta Trach river basin is now facing the risk of severe erosion (Institute of Natural Resources, Environment and Sustainable Development, 2011). Currently, there are various modelling techniques to assess soil erosion. SWAT (Soil and Water Assessment Tool) is well known as an effective model in researching soil erosion process, in order to manage natural resources and the environment as sustainable development (Garrity, DP, 1995; Le Van Du, 2011; Nguyen Kim Loi et al., 2011). The objective of this study is using GIS and SWAT toolkit to simulate soil erosion at Ta Trach river basin to assist policy makers in managing and protecting land resources in the basin.

\section{Materials and methodologies}

\subsection{Data sources}

The primary data used in this study were thematic maps of river basin, including digital elevation map (DEM), slope map, soil type map and land use map in 2005 and 2010, edited from land use map of Thua Thien Hue at the rate of 1: 25.000. In addition, ancillary data are also needed to run SWAT model, such as the type of land use, acreage, soil types, meteorological data (average daily air temperature, average daily rainfall observed in period from $1 / 1 / 2005$ to $31 / 12 / 2010$ ), and hydrological data at the same period of time.

\subsection{Methodologies}

\subsubsection{Collecting and processing data}

The required data for SWAT model were collected from various sources. DEM data were derived from SRTM data (Shuttle Radar Topographic Mission) of USGS / NASA, with spatial resolution of $30 \mathrm{~m}$. The land use map of study site was edited from the current land use map of Thua Thien Hue province in 2005 and 2010, including six types of land use: forest land, perennial crop land, annual crop land, water body, urban land and bare land. Soil map was obtained from soil map of FAO, at spatial resolution of 10 $\mathrm{km}$. Weather data (coordinates of measuring stations, daily rainfall data, and daily air temperatures) were collected from the Department of Natural Resources and Environment of Thua Thien Hue province. Due to limited data, only data measured at Thuong Nhat station $\left(16^{\circ} 07^{\prime}\right.$ north latitude, $107^{\circ} 41^{\prime}$ east longitude, at $415 \mathrm{~m}$ elevation) were used in the period from 2005 to 2010 .

The collected data were processed by ArcGIS 10.2 software to create thematic maps as standard input of SWAT 2009. Excel software was used to calculate the meteorological data (rainfall, temperature, wind speed and hydrological data such as flow input, output). Excel files were converted to standard input of SWAT by ForTRAN software. Thereafter, the calculation results were presented by Swatplot and Excel software.

\subsubsection{Modeling erosion by MUSLE tool in SWAT}

The model was developed to assess and predict the impacts of land use on water resources, the amount of sludge, and agricultural chemical production at large basin in long time. Erosion due to rainfall and surface runoff is estimated for the HRUs by MUSLE model (Modified Universal Soil Loss Equation), created by Williams (1975).

Sed $=11.8$

$\left(\mathrm{Q}_{\text {surf }} \times \mathrm{q}_{\text {peak }} \times \text { area }_{\text {hru }}\right)^{0.56} \times \mathrm{K}_{\mathrm{USLE}} \times \mathrm{C}_{\mathrm{USLE}} \times \mathrm{P}_{\mathrm{USLE}} \times$ $\mathrm{LS}_{\text {USLE }} \times \mathrm{CFRG}$

where, Sed is sediment yield in tones; $\mathrm{Q}_{\text {surf }}$ is the total flow spilled ground $\left(\mathrm{mmH}_{2} \mathrm{O} / \mathrm{ha}\right)$; $\mathrm{q}_{\text {peak }}$ is peak flow rate in $\mathrm{m}^{3} \mathrm{~s}^{-1}$; area are respectively, the soil erodibility in t.h.t $\mathrm{t}^{-1} \mathrm{~m}^{-1} \mathrm{~cm}^{-1}$, topography (dimensionless), crop management (dimensionless) and soil erosion control practice (dimensionless) factors similar to the USLE model (Williams and Berndt 1977); and CFRG is the surface roughness coefficient. The simulation results and model variation were based on indicators Nash.

\section{Results and discussions}

\subsection{Soil erosion of entire basin}

Table 1. Rainfall, surface runoff, and soil loss in the whole watershed from 2005 to 2010

\begin{tabular}{lccc} 
Year & $\begin{array}{c}\text { Rainfall } \\
(\mathrm{mm})\end{array}$ & $\begin{array}{c}\text { Surface } \\
\text { runoff } \\
(\mathrm{mm})\end{array}$ & $\begin{array}{c}\text { Soil } \\
\text { loss } \\
\text { (tons/ha) }\end{array}$ \\
\hline 2005 & 3457 & 1785 & 43.21 \\
2006 & 2946 & 1508 & 26.15 \\
2007 & 5874 & 4152 & 70.86 \\
2008 & 3321 & 1772 & 25.57 \\
2009 & 4205 & 2602 & 27.44 \\
2010 & 3271 & 1774 & 56.86 \\
Average & $\mathbf{3 8 4 6}$ & $\mathbf{2 2 6 5}$ & $\mathbf{4 1 . 6 0}$
\end{tabular}

As observed from output data of SWAT model, there were 35 sub-basins in study site, which covered an area of 
over 55.000 hectares. In term of percentage, the highest eroded occurrence of soil was in 2007 (70.86 ton/ha), in accordance with highest rainfall $(5873.904 \mathrm{~mm})$ and runoff surface $(4152.22 \mathrm{~mm})$, followed by the year of 2010 (56.86 ton/ha) and 2005 (43.21 ton/ha). Table 1 shows that soil erosion tends to vary with rainfall and surface runoff in following years.

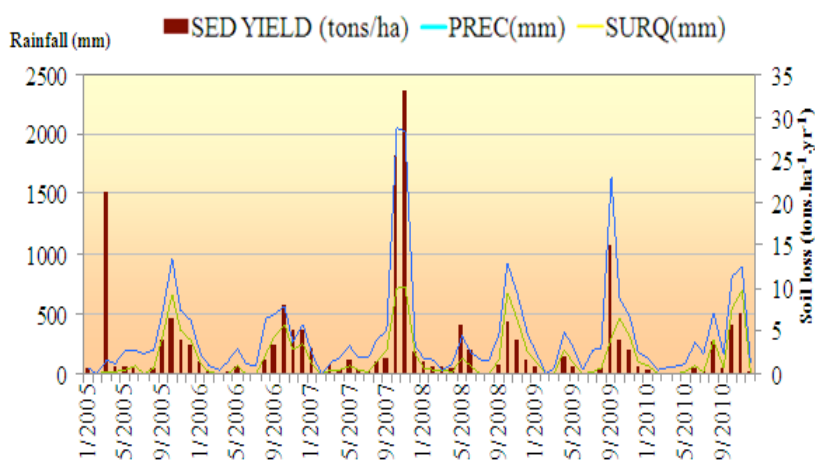

Figure 1. Monthly soil loss in the whole watershed ('SED YIELD: Soil loss (ton/ha); PREC: daily average rainfall of whole watershed $(\mathrm{mm})$; SURQ: monthly average runoff surface of entire basin $(\mathrm{mm})$ )

Figure 1 shows that rainy season of study site lasts from June to the end of December. The rainfall fluctuates differently among the months, and usually gets peak in October and November. Due to the river basin being in the monsoon tropical area, mainly rainy season, the flow regime could be maintained permanently. However, the runoff flow depends substantially on rainfall in the study basin. Accordingly, rainfall and stream flow are the primarily factors affected the soil erosion and sedimentation at the same time. Generally, sedimentation in river basin increased dramatically in the rainy season and decreased promptly the in dry season because of rapid reduction of forest cover. Therefore, water on the surface flow could not be retained. Consequently, the larger sedimentation of river basin was corresponding to the higher amount of soil erosion and declining water quality. The result also indicated that average annual soil erosion is around 41.6 tonnes/ha, which caused subsequently serious threat to land resources of entire basin.

\subsection{Soil erosion of sub-basin}

The data in Figure 2 show a close correlation between soil erosion and surface runoff during the studied period, except some years such as 2005, 2007 and 2008. The correlation is explained by the profound differences in soil types, land use types and slope of sub-basins. It can be seen as influential factors determining the amount of lost soil due to erosion.

The amount of lost soil due to erosion in sub-basin $13^{\text {th }}$ reached maximum value at 1.75 tonnes /ha in 2005, while the amount of lost soil in sub-basin $30^{\text {th }}$ was 119.67 tonnes /ha in 2007 (sixty-fold than sub-basin $13^{\text {th }}$ ). It is suggested that there is great disparity in the loss of soil between sub-basins due to their different characteristics such as area, width, height, soil type, land use, and slope.
The characteristics of two sub-basins influenced soil erosion are presented in Table 2.

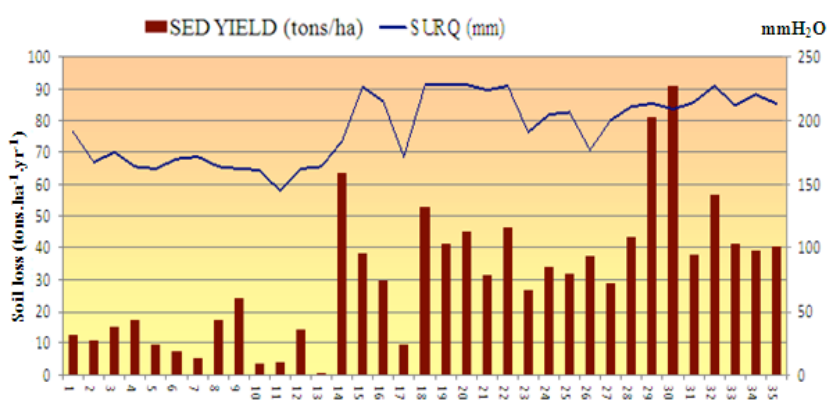

Figure 2. Average soil loss at sub-watershed from 2005 to 2010

('SYLD: Soil erosion (ton/ha/year); SURQ: average runoff surface of sub-basin ( $\mathrm{mm})$ )

\begin{tabular}{|c|c|c|c|c|}
\hline Name & $\begin{array}{l}\text { Land use } \\
\text { type }\end{array}$ & $\begin{array}{l}\text { Soil type in } \\
\text { FAO } \\
\text { UNESSCO }\end{array}$ & $\begin{array}{c}\text { Slope } \\
\left({ }^{\circ}\right)\end{array}$ & $\begin{array}{r}\text { Soil } \\
\text { loss } \\
\text { (tons/ha) }\end{array}$ \\
\hline 13 & Urban land & $\begin{array}{l}\text { Dystric } \\
\text { Fluvisols } \\
\text { (Fld) }\end{array}$ & $<8$ & 0.86 \\
\hline 30 & $\begin{array}{l}\text { Annual } \\
\text { crop land }\end{array}$ & $\begin{array}{l}\text { Ferralic } \\
\text { Acrisols } \\
\text { (ACf) }\end{array}$ & $>25$ & 91.09 \\
\hline
\end{tabular}

Regarding to sedimentation during the period from 2005 to 2010 , table 2 shows that sub-basin $30^{\text {th }}$ have the largest amount of sediment. It is believed that planted annual crops were the main impact factor because its cultivation mode could cause soil erosion. According to Nguyen Tu Siem and Thai Phien (1999), the topography of sub-basin $30^{\text {th }}$ is mostly mountainous with steep slope $\left(>25^{\circ}\right)$ and covered by yellow-red soil on magma acid rock, one of the erosion-prone soils in the hilly area. Meanwhile, the sub-basin $13^{\text {th }}$ covering by alluvial soil and used for urban purpose due to low slope of terrain $\left(<8^{\circ}\right)$ has a very low risk of erosion.

\subsection{Soil erosion of land use type}

The state of covered vegetation is extremely important for protecting soil in river basin. The research indicated that if the coverage of vegetation is lessened and trees with small leaf surface are planted in slope areas (such as cassava), the risk of soil erosion will increase under heavy rainfall.

Based on analytical results, it is assumed that small canopy trees can strongly influence the risk of soil erosion, especially annual crop land. As can be seen in table 3, even though annual crop land occupied just 1239.08 ha (2.25\% of total coverage), the amount of soil loss was quite high (3705.39 tons), counted at $31 \%$ and ranked as second land use type affecting soil erosion. The results are also shown that the average soil erosion under bare land was 6894.14 tons, representing about $59 \%$ of total soil loss in study area. Consequently, bare land was consid- 
ered as the most land use type caused soil erosion in Ta Trach river watershed from 2005 to 2010. Conversely, urban land had the lowest amount of soil loss within a span of six years (153.65 tons, representing $1 \%$ of total soil loss in study area) because of its substantial cover. In particular, the forest vegetation in study site was maintained as quite large area 22504.22 ha, which represented of $40.91 \%$. Therefore, the loss of soil due to erosion under this type of land use was the lowest (4\%). Perennial cropland such as fruit trees overlaid quite good surface of Ta Trach watershed over the last six years. Although covering as largest area (46.23\% of total coverage), the soil loss of this land use type is higher than natural forest type (5\%), because some areas of this land use type have been transferred to plant small canopy trees such as rubber, acacia and pine. Water body was the only type of land use in Ta Trach river watershed that has not been affected by soil erosion.

Table 3. Average soil erosion of land use type from 2005 to 2010

\begin{tabular}{llcr}
$\begin{array}{l}\text { Code in } \\
\text { SWAT* }\end{array}$ & $\begin{array}{l}\text { Land use } \\
\text { type }\end{array}$ & $\begin{array}{c}\text { Area } \\
\text { (ha) }\end{array}$ & \multicolumn{1}{c}{$\begin{array}{c}\text { Soil loss } \\
\text { (tons) }\end{array}$} \\
\hline FRST & $\begin{array}{l}\text { Forest land } \\
\text { Perennial crop }\end{array}$ & 22504.22 & 416.79 \\
& $\begin{array}{l}\text { PRCD } \\
\text { land }\end{array}$ & 25431.54 & 564.54 \\
& Annual crop & & \\
AGRR & land & 1239.08 & 3705.39 \\
WATR & Water body & 3251.17 & 0.00 \\
URBN & Urban land & 1792.39 & 153.65 \\
RNGB & Bare land & 877.53 & 6894.14
\end{tabular}

( Neitsch et al,2009)

\subsection{Assessing results of soil erosion model}

In this study, the simulated results were compared to the measured data by using NSE criteria (Nash, JE and JV Sutcliffe, 1970), and the percentage of deviation (Percent Bias - PBIAS) to assess the accuracy of the model. Observational data of current flow in year of 2005 and 2010 were analysed, in which data of year 2005 were used to correct model and data in 2010 was used to validate model.

* Calibration phase: observational flow data at Thuong Nhat station in 2005 was utilized to detect the model parameters. The analytical results show that Surlag (delay time of the overflow surface), $\mathrm{Cn} 2$ (permeable coefficient of soil surface), Esco (the amount of water loss due to evaporation), Alpha_Bf (runoff ground coefficient), Sol_Awc (effective water storage ability of soil), Gw_Delay (delay days of groundwater) were the parameters that strongly influenced the changes of flow in the river basin. Based on results of sensitivity analysis process, selected parameters were corrected to reach satisfied values and highest precision (Tran Thi Phuong, 2012).

* Validation phase: the model was tested by using parameters obtained in previous calibration process with time series from $1 / 1 / 2010$ to $31 / 12 / 2010$.
The quantitative analysis of predicted parameter's accuracy in year 2005 and 2010 are presented in Table 4.

Table 4. Results of calibration and validation model by daily measured and simulated flow data

\begin{tabular}{llcc} 
Content & Time & NSE & PBIAS (\%) \\
\hline Calibration & $\begin{array}{l}1 / 1 / 2005- \\
\text { Variation }\end{array}$ & 0.73 & 6.00 \\
& $\begin{array}{l}31 / 12 / 2005 \\
\text { 1/1/2010- }\end{array}$ & 0.89 & 9.62 \\
& $31 / 12 / 2010$ & &
\end{tabular}

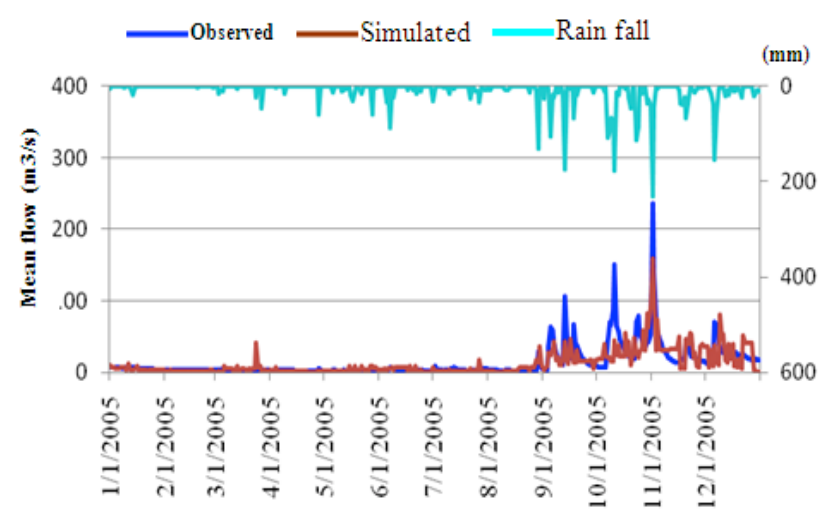

Figure 3. Comparison between actual and predicted data of flow in calibration process

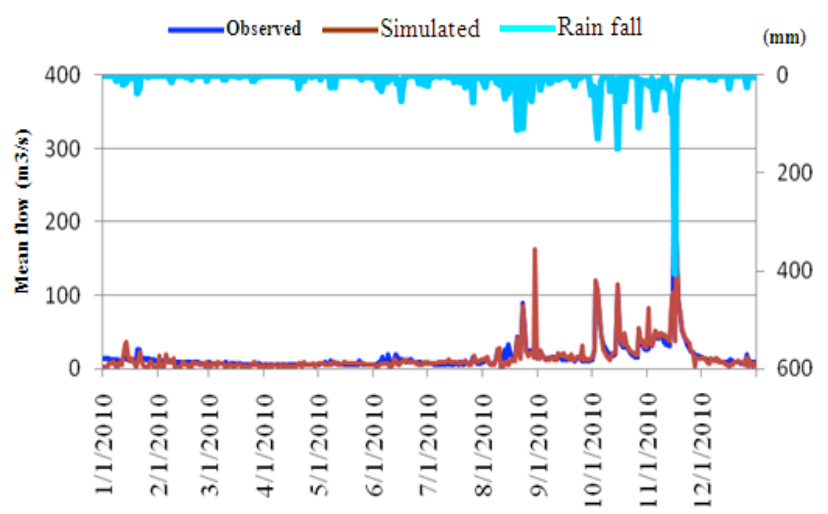

Figure 4. Comparison between actual and predicted data of flow in validation process

As can be seen from graph in Figure 3 and 4, a good coincidence between measured data and results calculated from model was recorded. The differences could be explained by the lack of actual data such as temperature, solar radiation, wind speed at the observational stations, insufficient number of stations. Although there are some mentioned restrictions, trends of simulated flow is consistent with the fact, therefore, the model is considered reliable and its results could be used for further studying.

\subsection{Soil erosion map}

Based on obtained data, the authors conducted a simulated soil erosion map at Ta Trach River basin. According to studies of Lai Vinh Cam (2000) and Vu Anh Tuan (2007), soil erosion is divided as five classes, including none, low moderate, severe, extreme rate (Table 5). 
Table 5. Soil erosion classes

$\begin{array}{cl}\begin{array}{c}\text { Soil loss } \\ \text { (tons/ha/yr) }\end{array} & \text { Soil erosion class } \\ <5 & \text { non } \\ 5-50 & \text { low } \\ 50-150 & \text { moderate } \\ 150-200 & \text { Severe } \\ >200 & \text { Extreme }\end{array}$

Table 6 Area of soil erosion class in Ta Trach river watershed

\begin{tabular}{cccccc} 
Level & Non & Low & Moderate & Severe & Extreme \\
\hline $\begin{array}{c}\text { Area } \\
\text { (ha) }\end{array}$ & 10737.54 & 30449.04 & 13020.53 & 62.03 & 826.79 \\
$\begin{array}{c}\text { Area } \\
(\%)\end{array}$ & 19.49 & 55.27 & 23.63 & 0.11 & 1.50 \\
\hline
\end{tabular}

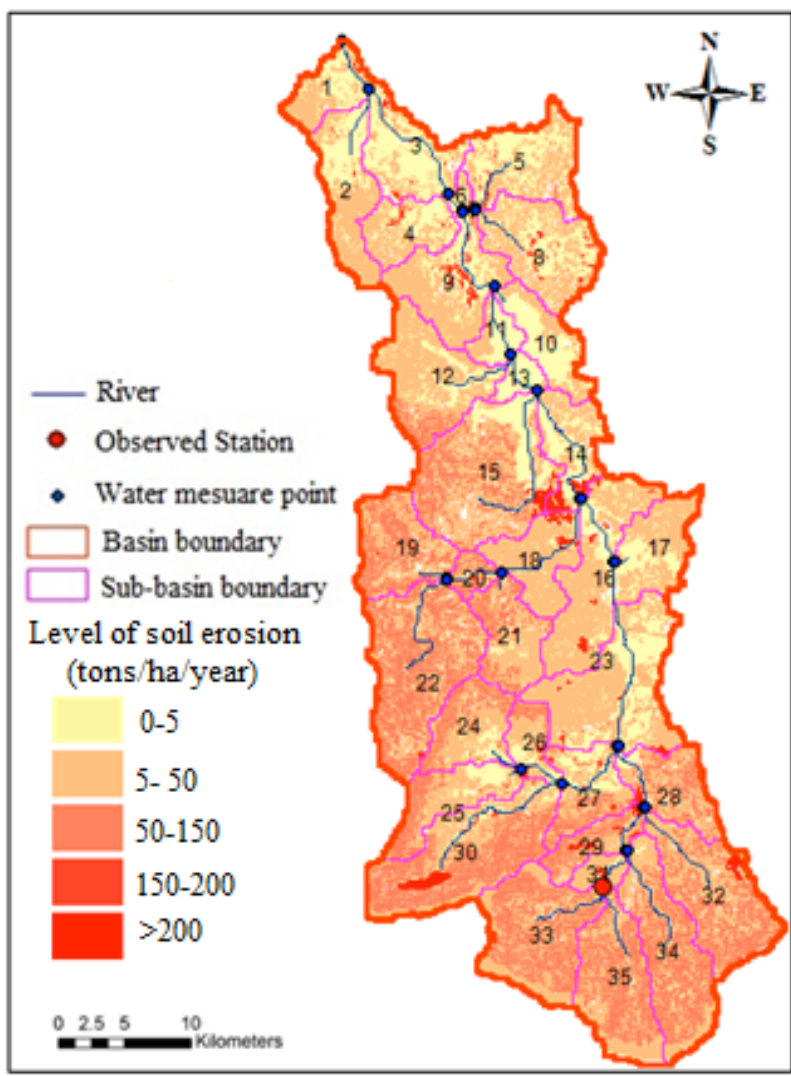

Figure 5. Soil erosion map at Ta Trach rive watershed from 2005 to 2010

According to output of SWAT model, area of each soil erosion class is calculated and presented in Table 6. It shows that the areas not influenced by soil erosion is 10737.54 ha, representing $19.49 \%$ of total studied area. Whereas, area of soil erosion at low rate is the majority at 30449.04 ha, representing $55.27 \%$ of total studied area. Only $0.11 \%$ and $1.5 \%$ of total area is influenced by soil erosion at severe and extreme rate, respectively.

\section{Conclusions}

The study selected observational station Thuong Nhat as the start output for the basin, from which model will automatically simulate a region with an area of 55.000 hectares over 90.000 hectares of entire river watershed.

The $30^{\text {th }}$ sub-watershed, located at Thuong Long commune, Nam Dong district, Thua Thien Hue province, had largest eroded volume. Whereas, sub-watershed $13^{\text {th }}$, located at Duong Hoa commune, Huong Thuy town, Thua Thien Hue province, was determined as least erosion area.

Soil erosion among sub-catchments was difference and changed over time due to their differences in climate, soil, vegetation. The amount of soil loss mainly concentrated in areas where slope is greater than $25^{\circ}$, the type of farming is AGRR (annual crop land) and on Ferralic Acrisols soil (ACf). In contrast, soil erosion rarely occurred in areas where land-use type is URBN (urban land), slope is less than $8^{\circ}$, and on Dystric Fluvisols soil (Fld).

Average soil erosion at Ta Trach river basin in span period of 6 years from 2005 to 2010 was 2.3 million tons, threatening extremely the land resources of the basin.

\section{References}

[1] Garrity. D.P. (1995). Improved agroforestry technologies for conservation farming: pathways toward sustainability. International workshop on Conservation Farming for sloping Upland in Southeast Asia: Challeges, Opportunities and Prospects. IBSRAM, Bangkok, Thailand. 14: 145168.

[2] Geoff Wright et al., (2006). Integrated-WaterResources-Atlas-of-Srepok- basin.

[3] Institute for Resources, Environment and Sustainable Development. (2011). General report on the status, trends in natural resources and environmental Huong river watershed, Hue.

[4] Lai Vinh Cam (2000). Soil erosion study in NorthWest region of Viet Nam by intergrating watersheed analysis and universal soil loss equation (USLE). Scientific Journal of National University of Hanoi, Natural Sciences No 11.

[5] Le Van Du (2011). Farming practices and soil quality. International workshop on vegetable agroforestry and Cashew-cacao systems in Vietnam. Ho Chi Minh City, Vietnam. WASWAC. 6a: 63-70.

[6] Ministry of Agriculture and Rural Development (2010). Degradation of water resources in river basins Vietnam, causes and solutions. Electronic portal, General Department of Irrigation, Hanoi.

[7] Nash, J. E. and J. V. Sutcliffe. (1970). River flow forecasting through conceptual models. Part I - A discussion of principles. J. Hydrology 10 (3), pp. 282-290.

[8] Nguyen Anh Hoanh (2010). Comprehensively studying geographical arising and land degradation aiming the purpose of reasonably using land 
resource and preventing disaster in Binh - Tri Thien region. Doctor of Philosophy Dissertation. Hanoi.

[9] Nguyen Kim Loi et al., (2011). Application SWAT for Nghia Trung subwatershed in Bu Dang district, Binh Phuoc province, Vietnam. International workshop on vegetable agroforestry and Cashew-cacao systems in Vietnam. Ho Chi Minh City, Vietnam. WASWAC. 6a: $207-219$.

[10] Nguyen Tu Siem, Thai Phien (1999), "Vietnam hilly land", Agriculture Publisher, Hanoi.

[11] Thua Thien Hue People's commitees. (2010, 2011, 2012). Thua Thien Hue geography.

[12] Tran Thi Phuong, Rajendra P. Shrestha and Yamagata Yoshiki. (2012). The impacts of land use chan- ge on soil erosion in Bo river watershed, central Vietnam, International Symposium on Geoinformatics for Spatial Infrastructure Development in Earth and Allied Sciences 2012.

[13] Vu Anh Tuan (2007). Studying current land use change and its effect on erosion in Tra Khuc River basin by Remote sensing and GIS. Doctor of Philosophy Dissertation. Institute of Science and Space Technology. Hanoi.

[14] Williams, J.R (1975). Sediment Yield Prediction with Universal Equation using Runoff Energy Factor, ARS-S-40. Agricultrual Research Servive, Washington, DC.

[15] Williams, J.R., and H.D.Berndt. 1977. Sediment yield prediction based on watershed hydrology. Trans. Of the ASAE. pp 1100-1104. 